World Bank Group And International Monetary Fund Support For Debt Relief Under The Common Framework And Beyond 


\section{INTERNATIONAL MONETARY FUND}

March 2021

\section{WORLD BANK GROUP AND INTERNATIONAL MONETARY FUND SUPPORT FOR DEBT RELIEF UNDER THE COMMON FRAMEWORK AND BEYOND}

IMF staff regularly produces papers proposing new IMF policies, exploring options for reform, or reviewing existing IMF policies and operations. The Report prepared by IMF and World Bank staff and completed on March 25, 2021, has been released.

The staff report was issued to the Executive Board for information. The report was prepared by IMF. The views expressed in this paper are those of the IMF staff and do not necessarily represent the views of the IMF's Executive Board.

The IMF's transparency policy allows for the deletion of market-sensitive information and premature disclosure of the authorities' policy intentions in published staff reports and other documents.

Electronic copies of IMF Policy Papers are available to the public from http://www.imf.org/external/pp/ppindex.aspx

\section{International Monetary Fund Washington, D.C.}


WORLD BANK GROUP

INTERNATIONAL MONETARY FUND

\title{
WORLD BANK GROUP AND INTERNATIONAL MONETARY FUND SUPPORT FOR DEBT RELIEF \\ UNDER THE COMMON FRAMEWORK AND BEYOND
}

March 25, 2021

Prepared by the staffs of the World Bank Group and the International Monetary Fund

\author{
Approved by
}

Marcello Estevão (WBG) and Jeromin Zettelmeyer (IMF)

CInternational Monetary Fund. Not for Redistribution 


\section{TABLE OF CONTENT}

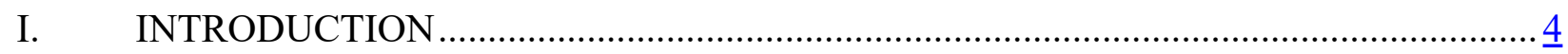

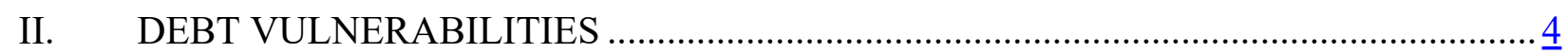

III. SHORT-TERM BREATHING SPACE: DSSI EXTENSION OPTIONS ………………..... $\underline{6}$

IV. TAILORED DEBT TREATMENT: MAXIMIZING THE IMPACT OF THE....

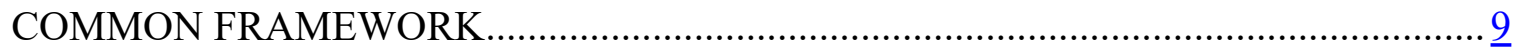

V. COMPLEMENTARY ACTIONS BEYOND THE DSSI AND COMMON.....

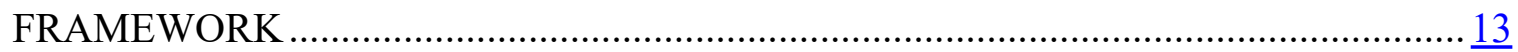

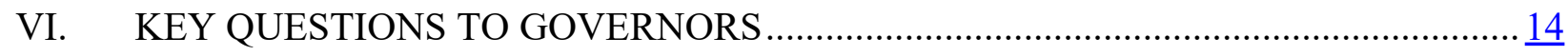

\section{FIGURE}

1. IDA-Eligible Countries: Risk of External Debt Distress …………….................................. $\underline{5}$ 


\section{LIST OF ABBREVIATIONS AND ACRONYMS}

\begin{tabular}{|c|c|}
\hline ASA & Advisory Service and Analytics \\
\hline $\mathrm{CF}$ & Common Framework \\
\hline DLP & Debt Limits Policy \\
\hline $\mathrm{DPF}$ & Development Policy Financing \\
\hline DPO & Development Policy Operation \\
\hline DRF & Debt Reduction Facility \\
\hline DSA & Debt Sustainability Analysis \\
\hline DSF & Debt Sustainability Framework \\
\hline GDP & Gross Domestic Product \\
\hline DSSI & Debt Service Suspension Initiative \\
\hline GRID & Green, resilient and inclusive development \\
\hline IDA & International Development Association \\
\hline IDS & International Debt Statistics \\
\hline IFI & International Financial Institutions \\
\hline IMF & International Monetary Fund \\
\hline LIC & Low-Income Country \\
\hline LIC DSF & Joint Bank-Fund Debt Sustainability Framework for LICs \\
\hline MDB & Multilateral Development Bank \\
\hline MOU & Memorandum of Understanding \\
\hline $\mathrm{PC}$ & Paris Club \\
\hline PPG & Public and Publicly Guaranteed \\
\hline SDFP & Sustainable Development Finance Policy \\
\hline SDR & Special Drawing Right \\
\hline TA & Technical Assistance \\
\hline WBG & World Bank Group \\
\hline
\end{tabular}




\section{WORLD BANK GROUP AND INTERNATIONAL MONETARY FUND SUPPORT FOR DEBT RELIEF \\ UNDER THE COMMON FRAMEWORK AND BEYOND}

\section{INTRODUCTION}

1. The October 2020 meeting of the Development Committee gave the World Bank Group and IMF a mandate to address debt challenges in low-income countries and to do so in a way that supports green, resilient, and inclusive development and poverty reduction. The Communique called on the Fund and the Bank to "review the debt challenges of low-income countries and propose actions to address their fiscal and debt stress". It also called on the Bank and the Fund to "help countries rebuild better, including promoting ... an inclusive and sustainable recovery... and addressing the challenges of economic and environmental vulnerabilities, including climate change." In an open letter, the Ministers of the Netherlands, Denmark, France, Spain, Germany and Sweden wrote: "We ask the World Bank and IMF to deliver on a coherent approach to debt restructuring. We need to make sure we do not lose sight of green and inclusive reforms because of limited fiscal space and a looming debt crisis."

\section{This paper discusses World Bank and IMF support for addressing fiscal and debt} distress in IDA countries, with emphasis on strong continued concessional flows for green, resilient, and inclusive development. It focuses on three support areas: (1) World Bank-IMF recommendations to the $\mathrm{G} 20$ on a potential further extension of the debt service suspension initiative (DSSI) until the end of 2021; (2) the IMF's and World Bank's role in implementing and maximizing the benefits of the Common Framework (CF) for Debt Treatments beyond the DSSI; (3) complementary actions beyond the CF. The actions proposed leverage the joint institutions' analytical expertise and knowledge to provide clear and consistent analysis for each country's financing needs and debt-carrying capacity, help develop country-by-country strategies for green, resilient, and inclusive development, and provide recommendations and facilitate decisions on debt treatments and the provision of concessional financing.

\section{DEBT VULNERABILITIES}

3. By the end of 2019 debt-vulnerabilities were increasing in IDA countries to the point of a renewed global spotlight on this agenda a quarter of a century after the inception of the HIPC framework. As of end-December 2019, 51 percent of IDA countries were classified by the IMF and the World Bank as either in or at high risk of debt distress (under the joint Bank-Fund Debt Sustainability Framework for Low-income Countries, LIC DSF), several of which had benefited from comprehensive HIPC debt relief. In some IDA countries, the interest burden already exceeded pre-HIPC levels — and debt service burdens are highest in Sub-Saharan Africa. Overall external public and publicly guaranteed (PPG) debt-service-to-revenue ratios for IDA countries increased from 8.2 percent to an estimated 11.8 percent between 2017 and 2019. The situation deteriorated during 2020, with 54 percent of IDA countries in or at high risk of debt distress. 
4. In contrast to the early 2000's, a significant number of IDA countries face high external debt service payments over the medium term, which could impede their ability to support the recovery. Debt Sustainability Analysis (DSA) for most IDA-eligible countries in an unsustainable or near unsustainable debt situation show large breaches of liquidity indicators (external debt service-to-export or external debt service-to-revenue ratios). Of 17 countries with protracted breaches of solvency indicators under the baseline (defined as breaches of solvency indicators over 5 years and more), 12 are also accompanied by protracted breaches of liquidity indicators (defined as breaches of liquidity indicators over 5 years or more). Five more countries have protracted breaches of liquidity indicators only.

Figure 1. IDA-Eligible Countries: Risk of External Debt Distress

(2013 to mid-Feb 2021; share of countries with LIC DSA)

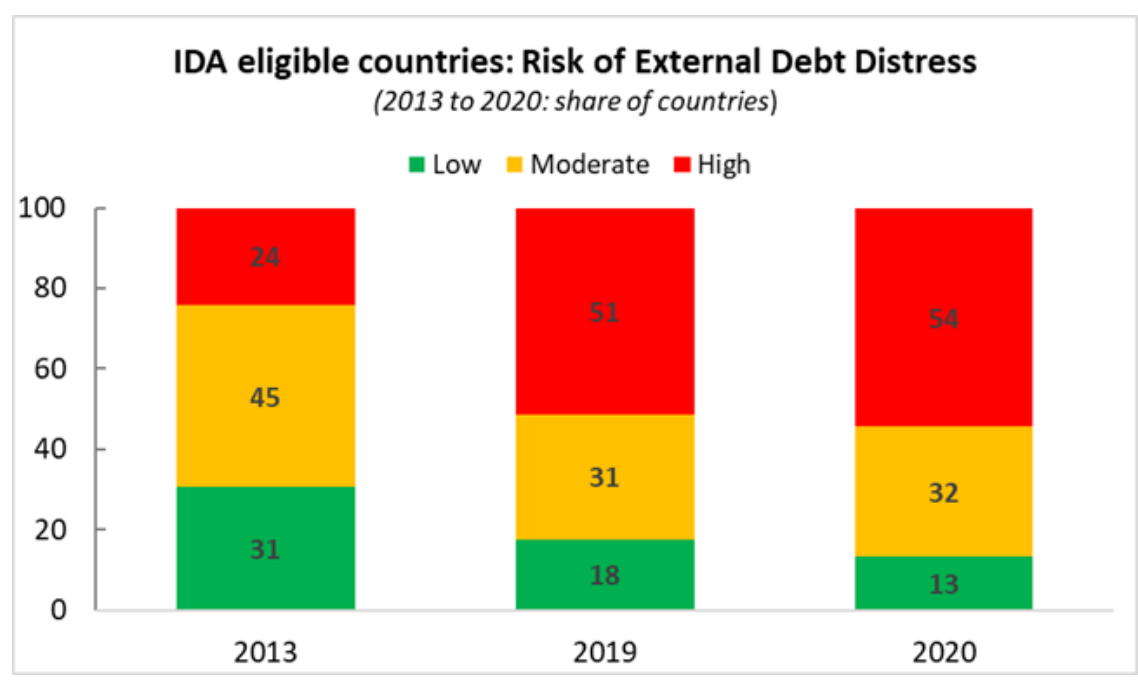

Source: Joint Bank-Fund LIC DSF Database, February 2021. The high-risk category includes countries assessed to be in debt distress.

5. The private creditor landscape has changed significantly over the last 20 years, and domestic debt has also risen rapidly in several IDA countries. Until the late 1990s, IDA countries borrowed primarily from official Paris Club creditors and IFIs on concessional, standardized terms. Borrowing from commercial sources mostly took the form of syndicated commercial bank loans and suppliers' credits repayable in equal semi-annual installments at fixed interest rates. Since then, the number of creditors and diversity of lending instruments have expanded rapidly (including in bond financing), with many instruments having complex structures, variable interest rates, and acceleration clauses. Private creditors' claims have become tradeable, exposing borrowers to volatile market sentiment and rollover risks. Claims that are at least partly collateralized or secured constitute a significant share of external debt obligations of some borrowers. The median domestic debt-to-GDP ratio in IDA countries covered by LIC-DSFs has almost doubled between 2011 and 2019 (from 7 to 13 percent of GDP), with non-resident holdings of local currency debt in some LICs reaching levels normally observed in emerging markets. 


\section{SHORT-TERM BREATHING SPACE: DSSI EXTENSION OPTIONS}

6. The World Bank, IMF and many other institutions have ramped up their support to respond to the health and economic impacts of the pandemic. The IMF and the WBG have significantly escalated their financial support for the poorest countries with the aim of providing significant positive net transfers. From April through December 2020, the IMF disbursed US\$18.5 billion (US\$ 16.4 billion in net transfers) to DSSI-eligible countries through its various facilities, including the CCRT. The World Bank (WB) committed US\$29.8 billion in IBRD and IDA financing to DSSI-eligible countries; its total gross disbursements to these countries (including IBRD, IDA and RETF) amounted to US $\$ 19.6$ billion, of which US $\$ 5.8$ billion on grant terms (US\$ 16.8 billion in net transfers). Financial support remains elevated in the first half of 2021.

7. The DSSI provided much needed additional fiscal space from debt service payments. The DSSI, endorsed in April 2020 by the Development Committee, the International Monetary and Financial Committee, and the G20 Finance Ministers, has been extended until end-June 2021 with the possibility to be further extended until end-2021. The DSSI has enabled a fast and coordinated release of additional resources to beneficiary countries that were severely affected by the COVID-19 crisis. The DSSI contributed to helping countries to respond effectively to the COVID-19 pandemic as it has been complemented by additional financing from the IMF, WBG, and other Multilateral Development Banks (MDBs). Given the severe and prolonged impact of COVID-19, the G20 agreed in October 2020 to extend the DSSI from end-December 2020 to endJune 2021 and to examine the need for a further extension in April 2021.

8. In these unprecedented circumstances, the DSSI continues to provide liquidity relief for the poorest countries in the world. In 2020, 43 countries benefitted from US $\$ 5.7$ billion (including participation by a national development bank participating as a private creditor) in debt service suspension from the initiative. ${ }^{1}$ The six-month DSSI extension through June 2021 could provide up to US\$7.3 billion of additional debt service suspension (from the same group of creditors) for the 45 countries that were DSSI participants as of February 16, 2021.2

9. The DSSI has continued to progress in enhancing transparency of public debt. The IMF and the WBG are supporting the implementation of the DSSI, including through monitoring spending, enhancing public debt transparency, and ensuring prudent borrowing. The WBG has published detailed data on external public debt and potential debt service suspension amounts from the DSSI based on the WBG's International Debt Statistics (IDS) database. This type of debt transparency is a high priority for sustainable development and recovery from the crisis.

10. Some challenges were revealed during the DSSI implementation that have since informed the Addendum to the April 2020 Term Sheet. Challenges comprise, especially, inconsistent application of terms and conditions for DSSI participation. The Addendum to the

\footnotetext{
${ }^{1}$ This estimate is based on information provided by G20 creditors as of November 2020.

${ }^{2}$ This estimate is based on debt-service payments owed to all official bilateral creditors as per the WBG International Debt Statistics (IDS) definitions and classifications. These estimates are derived from monthly IDS projections based on end-2019 external PPG debt. 45 participating countries have requested the DSSI either in 2020 or 2021.
} 
April Term Sheet seeks to address some of the challenges by clarifying, among others, the treatment of arrears, the application of higher interest, fees and penalties, the relevant limits on non-concessional borrowing, and the treatment of the syndicated loans. The absence of private sector participation in the DSSI has been a further challenge, which is important in view of the growing share of debt to the private sector in IDA countries. In this respect, the CF endorsed by the G20 (see below) would improve debt treatment efficiency in a tailored way for countries with unsustainable debt, along with countries with sustainable debt but facing liquidity issues or high debt vulnerabilities, while supporting fair burden sharing between the official and private sectors.

\section{As COVID-19 has continued to spread worldwide and the economic recovery remains} exceptionally uncertain, a further extension of the DSSI up to end-2021 would help eligible countries meet their elevated financing needs and fight poverty. ${ }^{3}$ Worldwide cases have multiplied, and new, more contagious viral strains have emerged. At the same time, developing countries and vulnerable populations risk being left behind in the global vaccine rollout. Liquidity needs are expected to remain high in 2021 and debt sustainability outlooks have deteriorated further. The economic outlook remains exceptionally uncertain at a time when many DSSI-eligible countries already have protracted breaches of DSA debt indicators. The World Bank estimates that to attain levels of vaccination coverage to interrupt virus transmission, Africa would need about US\$12 billion for vaccines and incremental costs for deployment, almost the same amount of official debt service deferred by current DSSI participants.

12. A comprehensive strategy — needed to address DSSI-eligible countries' financing and debt challenges - will take some time to implement. The IMF and the WBG are looking at ways to scale up concessional financing. The WBG has heavily frontloaded its resources to respond to IDA-eligible countries' most pressing needs in FY21 and is supporting countries' efforts to develop and implement their COVID-19 vaccination programs. It has started on the advanced IDA20 replenishment working closely with IDA Deputies and shareholders. The IMF is examining options to increase its concessional lending capacity, as well as a general allocation of new SDRs. While some measures can be effective immediately, others may take longer. The efforts on the financing side should be complemented by measures that directly address DSSI-eligible countries' growing debt vulnerabilities. In making their decision on a possible further extension of the DSSI, G20 creditors should consider the best ways to leverage all available tools, including a further DSSI extension until end-2021 and the CF endorsed by the G20 in November 2020.

\section{A key consideration for a further extension of the DSSI by six months should be its} possible role in paving the way for a smooth and effective implementation of the $\mathbf{C F}$. The DSSI is a rapid liquidity response tool that was introduced temporarily as an emergency response to the pandemic. So far, private creditors have not participated in the DSSI on a voluntary basis, limiting the benefits of the initiative. In addition, the DSSI does not provide incentives for

\footnotetext{
${ }^{3}$ A joint IMF-WB note for the G20 is being prepared with a fuller analysis of the economic and financial situation of the DSSIeligible countries, the experience with DSSI implementation, the observance of commitments made under the DSSI, the liquidity needs of DSSI-eligible countries and trends in their debt sustainability indicators, together with developments in LIC financing and debt treatments.
} 
countries to address debt levels where needed; risking to prolong unsustainable debt situations. It also contributes little to resolving protracted financing gaps. The $\mathrm{CF}$ aims at addressing these issues. However, at the early stages of its implementation, low income countries are still building their understanding of and confidence in the CF, which could limit its initial utilization relative to their needs. Therefore, a DSSI extension would help to provide countries with additional resources to address critical financing needs during the crisis, including related to the vaccine roll-out, while the CF becomes fully operational and is credibly established as an effective tool.

14. In this context, three options of the DSSI extension could be considered. These options would to a different extent address issues related to; (i) providing continued support to countries during this crisis; (ii) providing incentives for resolving unsustainable debt situations or protracted financing gaps; and (iii) ensuring a smooth transition towards the implementation of a CF. These options include:

- Option 1. A six-month extension of the DSSI for all DSSI-eligible countries. This option would avoid a gap in international support to DSSI-eligible countries and provide more time to establish the CF as an effective tool that can replace DSSI liquidity support while also delivering deeper debt relief when needed. It also allows time to implement concessional financing initiatives and a possible new SDR allocation. This option may, however, delay difficult-but-necessary restructuring decisions for some countries. So far, only three countries have requested a CF treatment, although 35 out of the 66 DSSI-eligible countries that use the LIC DSF are now assessed to be at high risk of debt distress or in debt distress. In addition, this option does not address G20 creditors' concerns about the lack of private creditor participation in the DSSI or debtor concerns about inconsistent DSSI implementation.

- Option 2. A six-month partial extension of the DSSI for those DSSI-eligible countries that have (or have requested) an IMF UCT-quality arrangement. This option avoids postponing a debt treatment for countries with unsustainable debts since the IMF can provide program support only for countries whose debts are sustainable. The total number of DSSI-eligible countries supported by a UCT-quality arrangement (currently 14) is expected to rise as 13 additional DSSI-eligible countries have already submitted a request. Similar to option 1, this option will provide time for the CF to be operationalized and better understood by debtors and financial markets, including for it to be more widely used to provide liquidity relief through debt reprofiling or rescheduling. While some countries may respond to the incentive to request an IMF UCT-quality arrangement, it may prevent some countries from benefitting from the DSSI, including because of domestic or external political factors, even as their fiscal space is more limited.

- Option 3. No further DSSI extension. This option would likely encourage more debtor countries to request an IMF UCT-quality program, as well as possibly a CF debt treatment, while increasing the urgency for creditors to implement the CF. It would also promote equitable burden sharing among creditors and provide more tailored debt treatments. 
However, it could contribute to financing difficulties in some countries, especially if the $\mathrm{CF}$ and other steps to enhance LIC financing take time to implement. Moreover, some countries currently benefitting from DSSI may not be prepared to request an IMF-supported program within the coming months, including because of domestic or external political reasons, in which case they also could not soon access the CF.

15. Taking all factors into consideration, while option 2 is most closely aligned with the broader strategy to comprehensively address countries' debt challenges and ensure countries can service their debt in the future, option 1 could come close to achieving the same outcome if the G20 were to publicly commit that this is the last extension of the DSSI. Option 1 would imply an extension on the same terms as the earlier DSSI extension through June 2021, thereby entailing a simple and predictable process for DSSI-eligible countries. Under option 2, the requirement of a request for an IMF-supported UCT-quality program could prevent some DSSIeligible countries from participating, although reduced DSSI support for some countries would be less costly if a timely general SDR allocation were implemented. A G20 announcement that this is the last extension of the DSSI would incentivize countries to move toward more permanent solutions to their debt situations, including through CF debt treatments, while providing some needed flexibility and liquidity to countries that are still coping with the fallout of the COVID crisis.

\section{TAILORED DEBT TREATMENT: MAXIMIZING THE IMPACT OF THE COMMON FRAMEWORK}

16. The Common Framework introduced by the G-20 recognized that, while critical, short-term measures alone are not able to address unsustainable situations or protracted financing gaps. Prompt, durable, and comprehensive debt relief by official bilateral and commercial creditors will be key to deal with unsustainable debt ${ }^{4}$ and to support countries with large and protracted financing needs. Such comprehensive yet case-by-case debt treatments can support essential public spending during a longer-than-expected recovery. The human and economic disruptions brought by the pandemic rule out fiscal consolidation as an immediate option to deliver sustainable debt trajectories. Once the recovery is underway, gradual fiscal consolidation will become necessary in many cases, but this must be undertaken in ways that not only protects essential social spending, including health and education spending, but also allows appropriate levels of public investment. In many IDA countries, this is unlikely to be feasible unless supported by grants or additional debt treatment, including debt rescheduling.

17. The Common Framework offers a structure for guiding agreements on debt treatments for eligible countries. It aims at providing debt treatments - including deep debt reductions when needed - to countries eligible under the DSSI. Key technical aspects of the CF have already been defined, including a cut-off date for debt eligibility (March 24, 2020), broad

\footnotetext{
${ }^{4}$ See Carmen Reinhart and Christoph Trebesch (2016) "Sovereign Debt Relief and its Aftermath", Journal of European Economic Association, February 2016.
} 
participation from all official bilateral creditors, and the requirement that the debtor seek comparable treatment from all its other official bilateral creditors and private creditors - a critical factor to ensure adequate burden sharing.

18. In the last three months, the G20 - in collaboration with the Paris Club Secretariat, the IMF, and the World Bank — has made progress in operationalizing the CF:

- The CF specifies a process "initiated at the request of a debtor country". The eligible country is required to send a formal request for debt treatment to all its G20 creditors as well as its Paris Club (PC) creditors (through the PC Secretariat).

- $\quad$ Once the formal request has been received, a dedicated creditor committee is formed. The committee acts as a group and decides by consensus. Members of the committee will have the authority to engage with other creditors, share relevant information, and provide financing assurances to the IMF on behalf of their respective authorities.

- $\quad$ The committee's tasks are to negotiate a debt treatment informed by the technical analysis and options included in the joint World Bank-IMF DSA and consistent with the parameters of a UCT-quality IMF-supported program, thereby facilitating the approval or implementation of that program. It also concludes a "Memorandum of Understanding" $(\mathrm{MoU})$ with the debtor country at the end of the negotiation. The debt treatment parameters laid out in this MoU guide bilateral negotiations for all G20 official bilateral creditors and form the basis of the comparability of treatment requirement applied to all remaining creditors.

- $\quad$ IMF and World Bank staff attend the meetings of the creditor committee as observers to provide technical input and information, in particular on the macroeconomic and financial situation of the debtor country, as well as on the status of Fund and Bank's engagement with the country.

19. Successful implementation of the CF for the initial cases of Chad and Ethiopia is critical to its broader success in overcoming the diverse debt challenges of low-income countries. Timeliness is key as both countries have pressing needs for financial support in the current crisis conditions. But timeliness cannot come at the expense of achieving a debt treatment that is insufficient to durably address the needs of each country. Achieving both these goals will require cooperation of official creditors that is unprecedented in scope to overcome roadblocks that could lead to delays. Hence, the strong support of the G20 - and of the IMF and the World Bank in their roles under the CF-will be essential. Success will benefit Chad and Ethiopia immediately, and will lay the basis for countries facing similar challenges to have confidence in seeking a debt treatment under the $\mathrm{CF}$ sooner rather than later.

20. Maximizing the impact of the $\mathrm{CF}$ entails using it to support all debtor countries that can benefit: 
- It is well recognized that the CF can coordinate debt treatments for DSSI-eligible countries with deeply unsustainable debt, where a debt reduction in net present value terms is often required to restore sustainability. Resolving unsustainable debt burdens is critical for the country to return to the sustained growth necessary to reach its development goals.

- $\quad$ But the $\mathrm{CF}$ also has the potential to play a broader role in supporting countries to recover from this unprecedented crisis. Even countries with sustainable debts are often facing large financing needs not only in 2021, but also in subsequent years. These will be challenging to meet without forcing faster-than-ideal fiscal adjustment. Furthermore, some IDA countries in which debt is still considered sustainable face high risks from elevated debt service ratios. In these circumstances, a rescheduling of debt service falling due in coming years can do much to ease financing pressures and facilitate a more gradual adjustment while protecting priority spending. At the same time, it is important not to undertake rescheduling alone when a deeper restructuring is needed.

21. The IMF and the World Bank must facilitate the success of the CF by supporting the implementation of comprehensive and durable debt treatments, based on the Joint World Bank-IMF Debt Sustainability Framework for Low-Income Countries (LIC-DSF). It is critical to ensure that both debt sustainability assessments and the envelope for the debt restructuring derived from these assessments are realistic, especially in recognition of the exceptional uncertainty surrounding macroeconomic assumptions in the pandemic environment. The IMF and the World Bank can contribute to this by ensuring that the macroeconomic and policy framework underpinning debt sustainability assessments is realistic and leaves sufficient room for priority social spending. WBG and IMF staff will present their views on these issues to the creditor committee, with the IMF taking the lead on medium-term macroeconomic projections and feasible medium-term economic policies, and the World Bank on longer-term growth prospects and structural reforms. The debt restructuring envelope will generally be sufficient to place countries at least into the category of moderate risk of debt distress over the medium term (or by the end of the IMF program period in IMF exceptional access cases), with the appropriate buffers (space to absorb shocks) to be determined case-by-case taking relevant economic risks into account, based on the joint WBG-IMF LIC-DSF and IMF program parameters. Sufficiently deep and comprehensive restructurings are essential to prevent the debtor from quickly relapsing into renewed economic and social stress, and also to attract new financing.

\section{The success of debt restructuring also hinges on sound policies, mobilizing adequate} financing, and structural reforms to durably contain debt vulnerabilities. A durable solution to debt distress will allow the World Bank, to deliver a larger share of its highly positive net flows in the form of quick-disbursing Development Policy Financing, consistent with its operations policy parameters. IMF program and WB DPF design must ensure that policies to put government finances on a sound footing support sustained inclusive growth by protecting essential social spending and through domestic resource mobilization. Providing new financing, predominantly on concessional terms, is critical during the restructuring phase and beyond, given very large financing needs and because some countries may lose access to private sector financing during the 
debt treatment phase. Sustained policies to improve debt management capacity, fiscal management, including related to domestic resource mobilization, spending composition and spending quality, and debt transparency are needed to accompany debt relief. Well-coordinated implementation of the recently reformed IMF Debt Limits Policy and the Bank's new Sustainable Development Finance Policy (SDFP) will be key to incentivize and build capacity for prudent debt management.

\section{The WBG and the IMF can also support the implementation of the CF through several additional channels:}

- $\quad$ Comprehensive and reliable public debt information. A sovereign debt treatment requires comprehensive disclosure of public debt in order to assess the nature and depth of treatment needed and give the creditors confidence in inter-creditor equity. The WBG and the IMF will facilitate debtors' efforts to provide these data and reconcile them with creditors' debt data to ensure their accuracy and comprehensiveness. Reconciled public debt data would need to be fully disclosed by the creditor and creditor groups. Active and timely data delivery from all creditors will be needed to perform this task.

- $\quad$ Debt Reduction Facility (DRF) of the WBG. The scope of the DRF was recently expanded to better meet the needs of IDA countries because of growing debt challenges. First, country eligibility was expanded to include all IDA-only countries and IDA-blend small states. Second, its scope was expanded to support the financing of legal and financial advisory services for external debt reduction operations and to support other assessments of contractual obligations in sizeable, complex debt and debt-related transactions. This support can play a critical role in enabling countries to develop and implement an effective strategy to engage with private creditors to ensure their participation in the debt treatment.

- Communications with country authorities as well as with the broader public. Communications by the G20, the Fund, and the World Bank have understandably given prominence to the role of the $\mathrm{CF}$ in resolving unsustainable debt. Yet, many countries with high financing needs but still sustainable debt could benefit from $\mathrm{CF}$ rescheduling or reprofiling, as this could enhance their fiscal space, smooth consolidation, and help limit financing stress. Making this option better known could help moderate market and credit rating agency reactions to $\mathrm{CF}$ requests and avoid discouraging countries from seeking a $\mathrm{CF}$ treatment for rescheduling purposes.

- Coordination with other institutions providing support in areas relevant for $C F$ implementation. This will be particularly important in areas where direct support from the WBG and the IMF is either not possible or limited. Specific challenges that CF-eligible countries may encounter when dealing with non-official creditors could include: (i) how to engage with creditors to determine the validity and value of their claims; and (ii) dealing with potential legal actions. Most CF-eligible countries have limited "in-house" capacity to address these challenges. 


\section{COMPLEMENTARY ACTIONS BEYOND THE DSSI AND COMMON FRAMEWORK}

24. The Bank and the IMF are supplementing their support to DSSI and CF implementation through additional channels, recognizing the need for a holistic approach to the challenge of containing debt vulnerabilities, and the importance of continued access to concessional resources to finance priorities for green, resilient, and inclusive development (GRID). Strengthening fiscal positions and access to new financing will be critical during the restructuring phase and beyond, given very large financing needs, and to address possible concerns about losing access to private sector financing during the debt treatment phase. Sustained policies to improve debt management capacity, domestic resource mobilization, fiscal management, and debt transparency are needed to accompany debt relief, as is comprehensive and reliable public debt data.

25. Meeting countries' GRID priorities calls for significant financial resources at a time of fiscal constraints and debt vulnerabilities, emphasizing the need to augment all sources of finance and using them effectively. This includes direct private sector funding especially non-debt flows, domestic revenue mobilization, and development financing. Strengthening fiscal positions include expenditure and revenue measures. There is scope for reforms that have both economic and environmental benefits via improvements in allocative and spending efficiency. On the expenditure side, improving public spending and investment efficiency, quality of public procurement, and accountability can ensure that expenditures yield high growth dividends and offset the impacts of fiscal consolidation. Emphasis can be given to green priorities and private sector solutions, including green stimulus packages with significant multiplier effects. On the revenue side, measures could include reshaping tax systems - i.e. broadening tax bases, enhancing progressivity (e.g. wealth tax), reforming subsidies, taxing carbon emissions and consumption of fossil fuels, and addressing tax avoidance. Policies and regulations that "green" the financial sector, such as disclosure and reporting requirements, with public-private partnership playing an important role in directing private investments to GRID, are important.

26. The IMF and the WBG play a role in advising members on policy options for addressing these fiscal constraints, helping client countries to mobilize private capital, and creating green investment opportunities. In addition to expenditure and revenue measures, countries with non-zero limits on non-concessional borrowing may consider green bonds where financial markets are sufficiently developed, and the mobilization of climate finance (e.g. IDA20, Climate Investment Funds), which countries can leverage to support GRID-type interventions. The IFC is also working with private sector players in need of refinancing or balance-sheet restructuring, while positively influencing their environmental footprint.

27. Most importantly in the current environment, the WBG, the IMF, and other partners will need to continue providing increased concessional flows to support LICs' ability to recover from COVID-19 and finance GRID. This includes continued access to concessional credits and grants, particularly for countries applying to the CF. Sustaining a high level of positive 
net flows at highly concessional terms to IDA eligible countries through a successful replenishment of IDA20 (FY23-25) will be key. For the IMF, support through a general SDR allocation would help to complement the DSSI and CF implementation.

28. For countries that are close to their debt limits, financing GRID will require sufficient grants and concessional lending which could be augmented by conditional debt relief or reprofiling. One way to mobilize these additional resources could be to link them directly to strategies related to climate change adaptation and promote green, resilient, and inclusive development, which are widely supported in both IDA countries and creditor countries. In this regard, the WBG and the IMF are working on an organizing framework for official bilateral and commercial creditors, supported by a dialogue with other stakeholders, for linking debt relief to country strategies for GRID. The World Bank and other MDBs could provide advice on recipient country commitments in the agreed areas and their implementation status.

29. The WB and other MDBs, with IMF support, will continue to help countries access private sector financing and explore the promotion of innovative financing structures consistent with GRID priorities. These will aim at increasing financial flows, including through first-loss guarantees, loans, and other financial intermediation where local capital markets allow it. The WBG intends to continue providing large positive net flows of public and private finance for interventions that deliver green, resilient and inclusive development benefits for developing countries.

30. The WB and the IMF will need to continue their efforts to tackle longer-term debt sustainability challenges. IDA has recently adopted the SDFP which takes a broader and more systematic view of drivers of rising debt vulnerabilities, especially in the areas of debt transparency, debt management, and fiscal management, with the aim of providing stronger incentives and a more proactive and systematic engagement at the country level. Similarly, for countries with IMF-supported programs, the IMF Debt Limits Policy helps incentivize prudent debt management and comprehensive debt disclosure and contributes to enhanced debt transparency. In addition to the policies themselves, IMF financed programs and Bank Development Policy Operations (DPOs) as well as accompanying Technical Assistance (TA) and Advisory Services and Analytics (ASA) will continue to be important avenues to support countries to implement reforms that tackle these debt vulnerabilities.

\section{KEY QUESTIONS TO GOVERNORS}

- Do Governors support Bank and Fund staff's recommendation to the G20 of a further sixmonth extension of the DSSI (either option 1 or option 2 as outlined in paragraph 15)?

- Do Governors agree that the IMF and the World Bank have a central role in facilitating the success of the CF by supporting the implementation of comprehensive and durable debt treatments?

- Do Governors support or have comments on additional actions to reduce debt burdens and free up fiscal space for GRID spending? 